\title{
Bile Acid Measurement
}

National Cancer Institute

\section{Source}

National Cancer Institute. Bile Acid Measurement. NCI Thesaurus. Code C74800.

The determination of the amount of bile acids present in a sample. 